\title{
CONDITIONAL SUBSCRIPTIONS TO THE CAPITAL STOCK OF CORPORATIONS.
}

The legal aspect of such a conditional subscription in what may be described as its contractual relation is thus analyzed in DesMoines Valley $R$. $R$. v. Graff (1869), 27 Iowa, 99: "If one promises to pay another a sum of money if he will do a particular act and he does that act, the contract is not void for want of mutuality and the promissor is liable, though the promissee did not at the time of the promise engage to do the act; for upon the performance of the condition by the promissee the contract becomes clothed with a valid consideration which relates back and renders the promise obligatory." Or, as is said in Toledo R. R. Co. v. Hinsdale (I888), I 5 N. E. (Ohio) 665: "Until the road was completed, the subscription could not become absolute. It was only an offer to become a shareholder, and until the contract should be performed the relation of the subscriber to the company as stockholder would not arise." Practically more important, however, than theoretical considerations above enumerated is the simple proposition readily deducible from all the cases, that when such a condition is found in a subscription to stock, the performance of it by the corporation is a condition precedent to a suit by the corporation to recover the amount of the subscription. ${ }^{1}$

1 N. Y. C. R. R. v. Johnson (1855), 30 N. H. 390 ; Lowe v. R. R. (1858), I Head. 659; Martin v. P. \& G. R. R. (1859), 8 Fla. 370; Wear v. Jacksonville R. R. (1860), 24 Ill. 593; Taylor v. Fletcher (1860), 15 Ind. 80; Ashtabula R. R. v. Smith (I864), I5 Ohio St. 328; R. R. v. Felt (I872), 52 N. H. 379 ; Mansfield R. R. v. Stout (1875), 26 Ohio St. 24r ; Mansfield R. R. v. Brown (1875), 26 Ohio St. 223; Santa Cruz R. R. $v$. Schwartz (1878), 53 Cal. I06; Brand v. R. R. (I886), 77 Ga. 506, suggesting that if the corporation has in any way put it out of its power to perform the condition, the subscription eo instante becomes void; Anthony $v$. Co. (I889), I6 R. I. 57I, an interesting case involving the right to issue preferred stock; Blake $v$. Brown (I8go), 45 N. W. (Ia.) 75I, discussing "an unreasonable time;" Armstrong v. Karshner (189o), 24 N. E. (Ohio) 897 , holding the subscriber liable upon performance of his own condition, although the corporation was remiss in its performance of duties imposed by the statute; Hudson Co. $\nu$. Tower (I892), 30 N. E. (Mass.) 465. 
The conditions contained in such contracts, of course, vary indefinitely in their nature, depending not only on the kind of corporation but on the special requirements of each particular subscriber. Certain classes of conditions have, however, become familiar by reason of the frequency with which they occur; such are those by which the subscriber is to obtain a contract for supplying the new company on favorable terms. ${ }^{1}$ But the commonest form of such condition is, in the case of railroad companies, that the company should locate or construct its road on a given route ${ }^{2}$ the special rule of interpretation governing this is explained in Miller v. Pittsburg $R$. $R$. (I 86I), 40 Pa. 237, where a subscription was made for twenty shares conditioned upon the railroad locating and constructing its road along the then proposed route; the road was located as prescribed, one instalment was paid as required, and subsequently the company failed, and by its failure the construction of course came to an end. It was held in a suit upon the subscription that considering the fact that the road was to be built only by means of the money obtained by such subscriptions, it would have been so manifestly impossible for the proposed work to be accomplished, were the construction contended for the proper one, that the mutual understanding

1 Wood's Case (r858), 3 DeG. \& J. 85 ; Simpson's Case ( I869), I. R. 4 Ch. App. 184. Probably the case best illustrating this point is Rogers' \& Harrison's Case (1868), L. R. 3 Ch. App. 363, holding in the case of two rival applicants for a position as the company's agent, that the one's subscription was conditional and the other unconditional, because, while both subscribed simply to obtain the appointment, the former had, and the latter had not, sent with his application a letter to the directors stating in express language the terms of his subscription.

'See, also, O'Neil $v$. King (I856), 3 Jones $I_{\text {. }}$ (N. C.) 519 , further exemplifying the sensible interpretation of such conditions by holding that a condition that a road be completed to a certain village is fulfilled when it is built to the suburbs; Trott $v$. Sarchett (1859), 10 Ohio St. 24I; Iane v. Brainard (1862), 30 Conu. 565; Cumberland Valley R. R. v. Baab (1840), 9 Watts, 458, saying "The right to deternine a question of location is a corporate one, and is paramount to public convenience. A company is not bound to take the best road, and upon the best ground that can be had by an unlimited outlay; it is enough for the public that it does the best it can with its means;" Mansfield R. R. $v$. Stout (1875), 26 Ohio St. 24x ; R. R. v. Parks (1888), 86 Tenn. 554. 
of the parties must have been that if the railroad once located its road as prescribed, and bona fidc announced its intention so to construct it, thereupon the liability to pay accrued, and the subscriber was not relieved from his liability by the subsequent insolvency of the company long after the payment was due.

This has become the established and uniform rule of interpreting such conditions, which appear to be special favorites of the law and generally supported. " Fort Edward Co. v. Payne (1857), I 5 N. Y. $58_{3}$, is a striking exception, the court there saying: "To allow subscriptions to the stock of a corporation to be received conditioned that a particular location of the proposed railroad should be adopted would be contrary to public policy, as by such means improper influences might be brought to bear upon the question of the location. The object had in view by the legislature in authorizing the forma tion of these corporations, was to benefit the public generally by providing for the construction of safe and commodious highways, so located as to be most convenient and beneficial. If the intent of the stockholders in such a company is allowed to control the question, such a location and such termini of the proposed road will almost invariably be adopted as will best subserve the public interest, whereas, if in order to procure the requisite amount of capital, subscriptions are allowed to be taken conditioned that a particular location or termini be adopted, public convenience will frequently be sacrificed to individual interest." 2 In reply to this argument it may be said that, while it would undoubtedly apply in those cases where by a special act of incorporation the precise line of the proposed railroad had been fixed by the legislative will, it is hardly entitled to much weight in the more familiar case, at the present time, of incorporation under general laws, under which it is submitted that public convenience cannot and should not prevail as against the wishes of those who are

${ }^{1}$ But See R. R. $v$. Jones (1865), 2 Colo. 574, holding that such location is of no avail if the route is subsequently abandoned.

${ }^{2}$ Macedon R. R. $v$. Snediker (1854), I8 Barb. 317, advances the same arguments and arrives at the same result. 
thereby authorized to subscribe to such an enterprise as they may prefer to undertake.

Generally speaking, the breach of a condition incorporated into the contract of subscription will relieve the subscriber from any liability; the cases are numerous and important, however, which hold that the subscriber, if he would stand on this right, must do so promptly and unreservedly, and very slight evidence of waiver on his part has been seized upon by the courts as constituting sufficient ground to estop him from asserting it. So, for example, in Selna, Etc., R. R. Co.v. Tipton (1 843), 5 Ala. 787 , the defence was that five dollars had not been paid on each share at the time of subscription, as prescribed by the act; it was proved, however, by the plaintiff that the defendant had both paid his original note for his own five dollars per share, and had taken an active part in the organization and management of the corporation. Such acts were held to amount to a waiver of defendant's original right to withdraw, and the corporation could either forfeit for the shares for non-payment of assessments or (as here) could bring an action at law, precisely as if the condition had not been violated.'

${ }^{1}$ Of course the company is not responsible for the guarantees made by its promoters to a subscriber : Braddock v. R. R. (I883), 45 N. J. I. 363 . Conditional offer to subscribe could only be accepted by board of directors or authorized agent, and not by several members of board, not shown to be quorum : Junction R. R. Co. v. Reeves (1860), I5 Ind. 238.

2 So, in Cabot, Etc., Bridge v. Chapin (1850), 6 Cush. 50, the court suggests that voting to do business, though aware that all the stock had not been subscribed, is a waiver of the subscriber's right to withdraw; Ryder i. Alton, Etc., R. R. Co. (I85r), I3 Ill. 516, infra; Mitchell v. Rome R. R. ( 1855 ), $17 \mathrm{Ga} .574$, where the charter prescribed that five dollars should be paid down on each share, and that the company might organize when three thousand shares had been subscribed, and it was held that such pre-payment was not a condition precedent to beginning business; Erie Pl. Road Co. $v$. Brown ( 1855 ), 25 Pa. 156 , another instance of a subscriber who failed to pay the " hand money" demanded by the act, being estopped from asserting his right to withdraw by attending meetings, voting, etc.; Fiser $\approx$. Miss., Etc., R. R. (1856), 32 Miss. 359, estoppel by subsequent payment which is a "substantial compliance" (same point decided in Black River \& W. R. Co. v. Clarke (I862), 25 N. Y. 208); Philadelphia, Etc., R. R. v. Hickman (1857), 28 Pa. 318; Haywood 
International Fair v. Walker ( $189 \mathrm{I}), 83$ Mich. 386, S. C. $47 \mathrm{~N}$. W. $33^{8}$, is an important modern illustration of the tendency so frequently noted in this chapter to investigate the real meaning of conditions and provisions either of the charter or by-laws, and having determined for whose benefit they were created, to hold that no one else can profit by their violation; and of the further tendency to decide that, in a case where so many different parties are interested upon such very different footings, even he who has the right to repudiate his contract must be careful to see that he does not subject himself to the great law of waiver. ${ }^{1}$ The usual preliminary agreement had been prepared and signed, and upon the faith of the signatures the company had made sundry expenditures and entered upon engagements; held, that defendants, who had attended the corporate meetings and acquiesced in these very

Plank Road Co. $v$. Bryan (1858), 6 Jones, 82 ; Excelsior Co. v. Stayner (188r), 25 Hun, 9I ; Ross $v$. Bank of Gold Hill (1888), Ig Pac. (Nev.) 243, where stockholders who had acquiesced in the acts of trustees and appeared to the world as stockholders were held estopped from setting up that the trustees were improperly elected, because by-laws prescribed that they must be stockholders; Webb v. Balt. R. R. (1893), 26 At1. (Md.) II3; Bibb $v$. Hall (I894), I4 So. (Ala.) 98 . See, also; Wight ${ }^{\prime}$. Shelby R. R. (1855), т6 B. Mon. 4 ; Lake Ontario, Etc., R. R. v. MIason (1857), I6 N. Y. 45I, denying the right of defaulting shareholder to profit by his own default; Vicksburg R. R. v. McKean (1857), I2 La. Ann. 638 ; I11. R. R. Co. v. Zimmer ( 1858 ), 20 Ill. 654 , emphasizing the fact that the ruling made is in the interest and on behalf of the other stockholders; Piscataqua, Etc. Co. v. Jones (I859), 39 N. H. $49 \mathrm{I}$; East Gloucestershire Railway Co. $v$. Bartholomew (I867), L. R. 3 Ex. 15 ; Swartout $v$. Michigan Air Line (1872), 24 Mich. 390 ; Garrett $v$. Dillsburg R. R. (1875), 78 Pa. 465, infra.

1 For other recent illustrations of the principle of waiver, see Amer. Homestead Co. v. Linigan (I894), I5 So. (La.) 369 ; Bibb v. Hall (1894), 14 So. (Ala.) 98; Wadesboro Cotton Co. ข. Burns (1894), 19 S. E. (N. C.) 238; Building Assoc. v. Chamberlin (I894), 56 N. W. 897, where the waiver by those who had organized the company and advertised it to the public was of the right to plead the unconstitutionality of the law under which it was organized; International Fair $v$. Walker (I894), 97 Mich. I59; Ogden Clay Co. $v$. Harvey (I894), 9 Utah, 497, where the company had authority to call in subscriptions in the manner called for in the contract or by-laws-a resolution upon this point having been passed, and defendant having paid three calls in accordance with its requirements, it was held that he, at least, could not assail its validity. 
enterprises could not defend upon the ground that the act of incorporation did not comprehend any preliminary subscription. Equally unsound was the further defence that the amount of stock provided for in the articles was greater than that set forth in the subscription paper, or that said amount had not been paid in; defendant was, indeed, a proper person to have taken advantage of the breach of these requirements, but he had estopped himself from so doing by consciously exercising his rights of ownership in the company after full knowledge of all deficiencies.

Two qualifications of the judicial disposition to favor conditional subscriptions must always be borne in mind. The first is that such a condition must be incorporated into the written subscription itself, otherwise it will be disregarded. Arguments of practical convenience unite to support the application of the familiar rule of evidence, i. e., excluding parol testimony to vary a written contract to this class of cases; for clearly the allowing any subscriber to rely upon any loose statements of an irresponsible agent would be simply opening the door to all kinds of fraudulent defences. It is not proposed here to trespass upon a subject which is peculiarly a part of the law of evidence, any more than to say that the strict rule was applied at an early date to these contracts of subscription, ${ }^{1}$ and seems to have been generally maintained even in those jurisdictions where the rule of evidence has been much broadened. ${ }^{2}$ But the rule does not apply in its severity where the offer is to prove that the failure to insert the condition in the writing was a fraud: Ins. Co. v. Burger (1877), 1o Hun. 56. In the second place, a subscriber upon a valid condition may waive his undoubted

\footnotetext{
1 President $v$. Van Ness (1824), 2 Cranch. C. C. 449; Kennebec R. R. $v$. Waters ( $185^{2}$ ), 34 Me. 369 ; N. C. R. R. $v$. Leach (1857), 4 Jones I. 340; New Albany R. R. $v$. Fields ( $185^{8}$ ), to Ind. 187; Evansville R. R. $v$. Posey (I859), I2 Ind. 363; Cincinnati R. R. v. Pearce (1867), 28 Ind. 502 ; Comth. v. Culver (r873), 69 Ill. 502; Stewards v. Town (1876), 49 Vt. 29 ; Masonic Temple $v$. Channell (1890), 45 N. W. 716; Wurtzbarger $v$. Rollng Mrills ( I89r), ro Ala. (So.) I29.

${ }^{2}$ Robinson v. R. R. (1858), 32 Pa. 334; Gelpcke v. Blake (1863), I5 Iowa, 387 .
} 
right to defend in an action brought to collect his subscription either expressly or (more commonly) by conduct which, in view of his knowledge of the facts, the court will regard as an estoppel. Of course, such conduct may be of a dozen different kinds, ${ }^{1}$ depending on the circumstances of each case; but there are certain well defined acts which the courts have held sufficient to constitute a waiver, as taking an active part as manager or agent for the new company, ${ }^{2}$ or even attending and voting at meetings of the promoters of the company, ${ }^{3}$ or urging others to go on with the work, ${ }^{4}$ or subsequent payments on account of stock subscriptions, ${ }^{5}$ or the giving of a note which is accepted as payment by the corporation. ${ }^{6}$ On familiar principles, however, it is clear that the acts of the kinds mentioned are not enough to constitute a waiver unless done with a knowledge that the condition has not been complied with; a fortiori is this true, if the subscriber can prove that his apparent acquiescence was due to a fraudulent deception by the company's agents and without any negligence on his part. If a payment, for example, has been made under such circumstances, or a note given, so far from being estopped as to the future, he may still rely upon the condition and sue

${ }^{1}$ Parks v. Eviansville R. R. ( 1864 ), 23 Ind. 567.

- ${ }^{2}$ Hutchins $v$. Smith (1865), 46 Barb. 235 ; Hanover Junction R. R. $v$. Grubb (1876), 82 Pa. 36.

${ }^{3}$ Bedford R. R. v. Bowser (1864), 48 Pa. 29 ; Auburn Ass'n v. Hill (I893), 32 Pac. (Cal.) 587, citing Light Co. $v$. Johnson (I892), 93 Cal. 546 ; Hotel Co. v. Callender (r892), 94 Cal. I20.

4 Reformed Church v. Brown (1859), I7 How. Pr. 287.

${ }^{5}$ Nichols $v$. Burlington Plank R. Co. (1853), 4 Greene, 42 ; Cornell's App. (1886), 5 Cent. (Pa.) I8r ; Mack's App. id, I86.

${ }^{6}$ O'Donaid $v$. Evansville R. R. (1860), 44 Ind. 259; Evansville R. R. v. Dunn (I86r), I7 Ind. 603; Chamberlain v. Painesville R. R. (r864), 15 Ohio, 225 ; Slepher $v$. Elarhart ( 1882 ), 83 Ind. 173 , contains an interesting discussion of the doctrine: "The execution of the note being procured by fraudulent means, inducing the payer to believe that the condition of the subscription has been performed, rebuts all presumption of an intention of the parties to waive the condition. Cf. Taylor $v$. Fletcher, I5 Ind. 80 . But where an unconditional note has been executed in discharge of a conditional subscription, unless there has been fraud in procuring the executing of the note, it will be a waiver of the condition in the subscription." 
to recover back the money paid, or defend a suit on the note, as the case may be.

In strong contrast to the rule heretofore laid down is the opinion which seems to have been specially favored in the courts of Pennsylvania, though receiving a less hearty support in New York. Bavington v. Pittsburg R. R. (1859), 34 Pa. 358 , may be taken as an illustration of an early leaning in this direction, but the court was relieved from an actual decision upon the validity of conditional subscriptions, by the fact that defendant was himself the commissioner who had obtained subscriptions and certified to the governor that the requisite number had been obtained, and he was held to be estopped from setting up that he had in his own case exceeded his authority by making with himself a conditional contract.

- But in the same volume ${ }^{1}$ the court found itself squarely confronted by the question unaffected by any consideration of official delinquency, and meeting the question fairly, unanimously held, first, that conditions of any kind attached to a subscription to a corporate and public enterprise are ipso facto against public policy and void; and, secondly, that, as it is only the condition itself that is void, the balance of the contract including the subscription proper is valid and enforceable. ${ }^{2}$

\footnotetext{
${ }^{1}$ Pittsburg R. R. v. Biggar (1859), 34 Pa. 455.
}

${ }^{2}$ Chamberlain $v$. Painesville R. R. (1864), 15 Ohio, 225, where the condition was "provided the road is permanently located (on a given route) and that a freight depot be built (at a point named)." The road had been located as required, but the depot was lacking; it was held, however, that by the language of the agreement there was clearly not a condition precedent to enforcing the subscription, but a mere executory stipulation, for breach of which defendant might set off any damages he could prove, and that this prima facie construction was strengthened by the fact that defendant had paid assessments and voted to continue the work before the depot was located. The court thus seems to be drifting away from the original view that all conditional subscriptions are per se void as against public policy, and trying to discover some ground for holding such subscriber liable. Johnson $v$. Georgia, M. \& G. R. R. (I889), 8 S. E. (Ga.) 53I, where a subscriber was held liable upon his instalment notes, the requirements of the notes that the railroad should secure a certain privilege and be run independently of another railroad, being held to be not conditions precedent to enforcing the subscription, but merely specifications of what it was to be ultimately. 
The first point is one in regard to which opinions may fairly differ, although we have seen that a large majority of the courts look with complacency upon such conditions; but assuming the first point to have been properly decided, it is submitted that the consequences enunciated in the second are indefensible on either theoretical or practical grounds. On theoretical, because in no class of contracts is a party bound to carry out a program to which he never consented, unless, indeed, it be in those fraudulent or immoral agreenents where the courts keep their hands off, applying the maxim potior est conditio possidentis (and even there, of course, no judicial aid can be obtained); and on practical, because such conditions are, as a matter of fact, usually readily impressed upon the simple contract by energetic agents who are unwilling to lose a subscription from an honest but ignorant applicant, so that the hardship on the latter (who has acted in good faith) is obvious when the company, avoiding the unauthorized act of its promoter, collects an unwilling debt, and profits by the misdeed of its own employe. ${ }^{1}$ The doctrine was considerably modified in its practical bearing by the subsequent decision of Pittsburgh R. R. v. Stewart (I861), 4I Pa. 54. Defendant had, in a manner immaterial for our purposes, been released from his initial subscription, but after the company had begun to operate had been induced by the president, with the knowledge of the board, to take stock, on the understanding that it might be paid for in material. It was held that, conceding such a condition would have been held invalid, if incorporated in a preliminary subscription, yet the rule invoked did not apply to a subscription made

${ }^{1}$ See Troy \& B. R. R. v. Tibbits (1854), I8 Barb. 297; Downie $v$. White (I860), 12 Wis. 176 ; Andrews v. Ohio R. R. (1860), I4 Ind. I69; Bedford R. R. v. Bowser (1864), 48 Pa. 29; Whitehall R. R. v. Myers (1872), I6 Abb. Pr. N. S. 34; Miller v. Hanover Junction R. R. (1878), 87 Pa. 95 ; Chouteau Ins. Co. v. Floyd (I88I), 74 Mo. 286. Miller $v$. Hanover Junction R. R., supra, advances the additional argument in favor of this line of decisions that such a preliminary subscription is not only a future undertaking with the company, but also a present agreement with the other subscribers. Sharswood, J., describes the Pennsylvania doctrine in Nippenose Mfg. Co. v. Stadon (187I), 68 Pa. 256. 
after the company was actually organized. The court, relying upon the analogy of an increase in the capital stock of a going concern, when no subscriber can rely upon the fact that the whole of the proposed increase has not been subscribed for, ${ }^{1}$ decided that creditors, the only parties interested, must be presumed to have given credit upon the faith of the least amount with which the company could do business, and had no difficulty in sustaining a verdict for the defendant. In Caley v. Plizladslpliza \& $R$. $R$. (1876), $80 \mathrm{~Pa}$. 363 , the court held its ground, taking the further distinction between the acts of commissioners appointed by law for a restricted purpose only, and the acts of agents of a company which can sufficiently provide for its own interests; the distinction is an interesting one, although the adoption of it appears to involve an unwilling abandonment of the argument in the prior case, based upon creditors rights, for non constat that a corporation able to provide for its own interests will be equally solicitous for the rights of creditors.

A more logical view, and one whose practical consequences are not far removed from those following the prevalent American rule, is found in the English decisions, of which Pellatt's Case (1867), L. R. 2 Ch. 527 , is a leading example. The agreement here was that Pellatt should pay for his shares, thirty shillings apiece in cash, and that the calls for the balance should be paid in the profits of the goods with which he was to supply the new company. Though he received no formal letter of allotment, his name was put upon the list, and he even paid a deposit of ten shillings per share, yet, at the winding up, three years later, he was held relieved from the general liability of a stockholder. The court hesitated much in expressing an opinion upon the legality of such subscriptions, although inclining apparently to the view that they are ultra vires; but contented themselves with the dilemma that " the agreement, if ultra vires of the directors was not binding on the company, and, therefore, for want of mutality not binding on Pellatt. If, intra vires, it was not enforceable against

${ }^{1}$ Nutter $v$. Lexington R. R. (1856), 6 Gray, 85. 
Pellatt, for the stipulations on the part of the company . . . . had become incapable of being performed." This line of argument, convincing as it is, is very popular with the English courts, which have had no hesitation in accepting both the decision and the reasoning upon which it was based. ${ }^{I}$

Another incident so closely associated with the contract of subscription as, perhaps, to be more properly treated in that connection than under the head of conditional subscriptions is the method of paying for stock ; must payment be made in cash only, or is it competent for the company and the subscriber to agree that payment may be had in some kind of commodity suited for the purposes of the corporation? In the early cases, in the absence of an express clause in the charter, to the contrary, subscriptions were on supposed grounds of public policy, held payable in cash only; so, in Eppess v. Mississippi $R$. R. (1859), 35 Ala. 33, where the charter allowed a subscription to be paid in work " at public letting or private letting," it was held that the company could not sue until an opportunity had been afforded to the subscriber of making

${ }^{1}$ See Harrison's Case (r863), L. R. 3 Ch. 632, where the opposite conclusion was reached, because the subscription was on its face unconditional, the condition being hardly more than a reservation in Harrison's mind; Rogers's Case, id. 632, where, upon the same facts, Rogers was relieved because he had expressed his condition to the company; Simpson's Case (1869), I. R. 4 Ch. 184, where Simpson was relieved on the ground that the company had by its failure rendered itself unable to perform the condition upon which it had expressly accepted the subscription.

Joy v. Marion (1887), 28 Mo. App. 55, is an American decision in which the argument of the court closely resembles that used in the English cases. Defendant had agreeed to take twenty-fire shares of the new company upon an agreement by its promoter, that the company, when organized, would buy certain machinery of him. He signed the articles of incorporation as an original subscriber, though, as he testified, really ignorant of their contents and purport, and supposing that the contract with him was included. He was, of course, held liable on his subscription, his only right being an action for breach of the company's agreement (if he could prove it) and not to escape his own assessment.

Cf. Shaffner $v$. Jefferies (1853), I8 Mo. 512, where it was held that the fulfilment of the stipulation, that a committee would see to it that all the stipulations were complied with, was not a condition precedent to enforcing a subscription: Cornell's App., 5 Cent r8r. 
his election, but that after a reasonable time had elapsed since the subscriber had been given notice to elect without his doing so, the subscription became payable in cash.'

The early rule, above stated, has been entirely superseded by the modern decisions which, in effect, allow the shares to be paid for, unless otherwise provided by statute or charter, not only in cash, but in any labor, services, or material that are reasonably necessary to, and useful for the purposes of the corporation. ${ }^{2}$

The law is thus summed up in Wetherbee v. Baker (I882), 35 N. J. Eq. 50I : "The earlier cases held that the contract of the subscriber could only be fulfilled by payment in money. In later cases this doctrine has been relaxed, and stock issued and paid up in work and labor or in the purchase of property the corporation is authorized to hold, has been held to have been legally issued. . . . . But in all such cases, transactions under such powers have been upheld only where the contract for the rendition of services or the purchase of property payable in stock has been made in good faith; and the property taken in payment of stock subscribed has been put in at a fair bona fide valuation."

The only requisite is, as just indicated, that the valuation be fair and bona fide, in which event the law regards the subscription as having been paid in cash, and the cash used in the payment of labor or property.

Pell's Case (I869), L. R. 5 Ch. I I, is an equally emphatic expression of the English courts to the same effect, the particular application of the rule there being the release from any further liability, whether to the company, its liquidator, or its creditors, of one who had under an express agreement subscribed to the stock only under an express agreement that

\footnotetext{
${ }^{1}$ See Crocker v. Crane (1839), 2r Wend. 2Ir, refusing to recognize payment in checks; People v. Troy House Co. (1865), 44 Barb. 625, where charter prescribed payment in money only.

${ }^{2}$ Drummond's Case (1869), L. R. 4 Ch. App. 772 ; Foreman 2 . Bigelow (I878), 4 Cliff. 508; Phelen v. Hazard (I878), 5 Dill. 45 ; Cheraw R. R. $v$. Garland (1880), I4 S. Car. 63; Liebke v. Knapp (1883), 79 Mo. 22; Coffin $v$. Ramsdell (r886), I Io Ind. 4I7; In re Jones, Lloyd \& Co. (I889), 4I Ch. Div. 159 .
} 
certain work or materials of his should be accepted in payment. Of course, the requirement that the article furnished, whether labor or materials, must be taken for this purpose only at its fair value was rigidly insisted on. ${ }^{1}$

Reynolds D. Brown.

1 In addition to the cases heretofore cited, see N. Y., H. \& N. R. Co. v. Hunt ( 1872 ), 39 Conn. 75, where, under similar circumstances, the contractor was held not to become a stockholder until he had earned and received his stock; Mann $v$. Cooke ( 1875 ), 43 Conn. 86 ; Magee $v$. Badger (1859), 30 Barb. 246, where directors, under a charter power, had authorized the acceptance of a promissory note in payment; R. \& C. R. R. v. Stewart (186I), 4I Pa. 54, holding that one who had contracted to pay in materials did not waive his right by making a part payment in cash; Noble $v$. Callender (1870), 20 Ohio, I99, where the subscriber unsuccessfully attempted to set up an agreement to receive land in payment; Tuckerman v. Brown (1865), 33 N. Y. 297 ; Dent's Case (I873), L. R. I5 Eq. 407, deciding that such an agreement is no defence if, as a matter of fact, the payment is not made in the manner indicated; Spargo's Case (1873), L. R. 8 Ch. App. 40\%, where the issue of all the stock of a company in return for the mine furnished by Spargo was held legal; C. \& C. R. Co. $v$. White (r88o), I4 S. C. 5 I ; Coit $v$. N. Car. Gold Amalgamating Co. (1886), 7 Sup. Ct. 23I, where Field, J., said: "Where the charter authorizes capital stock to be paid in property and the stockholders honestly and bona fide put in property instead of money in payment of subscriptions, third parties have no ground of complaint. ... Where full paid stock is issued for property received there must be actual fratid in the transaction to enable creditors of the corporation to call stockholders to account. A gross and obvious overvaluation would be strong evidence of fraud;" Poole v. Butter \& Cheese Assoc. (1887), 3 Fed. 513, where an incorporation, in this regard contrary to law, was held valid and binding as between the parties to it; New Orleans \& G. R. Co. $v$. Frank ( I887), 2 So. (La.) 3Io; Ambler 0 . Archer (1894), I App. D. C. 94, holding that a stockholder who has not himself paid cash, may not demand that other stockholders shall; Coffin $v$. Ramsdell (1886), rro Ind. 417 , probably the leading modern authority recognizing the doctrine to the fullest extent, at the same time that it condemns any fradudulent or simulated subscriptions.

The whole matter is sometimes thought so important as to warrant constitutional provisions : see Const. Ala., Art. XIV, \& 6, "No corporation shall issue stock or bonds except for money, labor done, or money or property actually received; and all fictitious increase of stocl- or indebtedness shall be void." 